\title{
Securing water sustainability through innovative spatial planning
}

\author{
H. E. Rohr ${ }^{1} \&$ W. Fourie ${ }^{2}$ \\ ${ }^{1}$ North West University Potchefstroom, South Africa \\ 2I@Consulting Pty.Ltd, South Africa
}

\begin{abstract}
Planning in South Africa operates within a legal framework, which strives to ensure that municipalities deliver their developmental duties (in terms of Section 153 of the Constitution). South Africa's approach to Spatial Planning and Land Use Management is undergoing major changes in order to escape from our legacy of apartheid planning, as well as to ensure sustainable development and better management of municipal land. However, the increasing urbanisation, densification and related urban challenges of the modern urban environment is also increasing the pressure on sustainable resources exponentially. South Africa is a water scarce country, and all predictions points to global warming exacerbating this problem. The science of urban planning focusses both on designing the future shape of our cities, as well as managing the current land uses present in our towns and cities. In the past, land use planning has often been divorced from infrastructure planning (e.g. water) to the detriment of sustainable cities. The new legislation enacted in August of 2013 Spatial Planning and Land Use Management Act (SPLUMA) promotes a much closer link between planning for land use and planning for infrastructure. The study focusses on ways that spatial planning and land use management can contribute to water management within the built environment. The aim of the study is to provide a strategy to deliver the most sustainable water services infrastructure at the right time and location to enable and optimise existing and future development.
\end{abstract}

Keywords: water sensitive planning, land use management, integrated spatial planning, South Africa Spatial Planning and Land Use Management Act. 


\section{Introduction}

We spend our whole lives worrying about the future, planning for the future, trying to predict the future [1]. This is very much the same in the urban planning profession. Since the 1950s, Town Planning theories were preoccupied with visionary plans and designs that showed how the ideal town or city should be spatially organised [2]. Nowadays, urban planning is often viewed by others as simply developing drawings and images of the city in the future, without discerning how the process and the decisions it requires can become the backbone of urban transformation. Fact is, Urban Planning is not about images, but a way to make a difference; it is a framework that helps municipalities to transform a vision into reality by using land and space as a key resource for development. Many argue that twenty-first century urban planning must take place with a full understanding of current and future urban challenges such as demographic; environmental; economic; social-spatial; and institutional challenges in order to foster sustainable development [3].

Some people believe that without history, our lives amount to nothing [1]. At some point, we all have to choose. Do we fall back on what we know? Or, do we step forward, to something new? If we look at the theory of spatial planning, the paradigm shift towards sustainable development "development that meets the needs of the present without compromising the ability of the future generation to meet their needs" [4] was without a doubt a step in the right direction. Developed countries such as Sweden; Australia; Switzerland and Denmark has embraced this planning theory to its fullest and is rated as the top 4 most sustainable countries in the world, whereas developing countries such as South Africa, India and Russia are still struggling to combine this theory into their reality [5].

Among the greatest challenges of the twenty-first century is the increasing growth of cities [6]. Over the last century, our world is rapidly becoming predominately urban, for example, even though Africa and Asia are amongst the least urbanised continents, they have the fastest rates of urbanization in the world [3]. As such these cities embody some of society's most pressing challenges, as diverse as high percentages of people living in slums; expansion and dominance of the informal sector; inadequate urban basic services (especially water), social and political conflict over land resources, climate change, and environmental degradation [7].

While these challenges may seem insurmountable to many, history has shown that urbanization leads to development, and development is key to unlocking innovative thinking [8]. Developing counties do not have the luxury of centuries of learning to adapt to growth. There is no better time than the present to introduce innovative, multidimensional and effective evidence based planning practices by improving the connection between research and professional work to support sustainable urban development and to overcome the urban challenges presented by rapid population growth [9]. 


\section{Current realities}

Planning is a future orientated profession. In order to plan sustainably, we need to know what and who we are planning for and most especially what we have to plan with. This section will explore current realities in South Africa along the following themes: climate, demographic indicators and urban form.

\subsection{South Africa is a dry country}

South Africa has low levels of rainfall, $450 \mathrm{~mm}$ per annum relative to the world average of $860 \mathrm{~mm}$ per annum [10]. Contributing to the water scarcity in South Africa is the high level of evaporation due to the temperatures of annual mean above $17^{\circ} \mathrm{C}$ [11]. The low rainfall, high temperatures and evaporation results in South Africa being the $30^{\text {th }}$ driest country in the world [10]. Infrastructure such as dams provides the country with a source of water. In order to ensure the reliability of this source it needs to be protected trough policy and planning tools at all levels of government. South Africa has 89 large dams and 19 major Water Management Areas (WMAs) which stores more than two thirds of the country's mean annual runoff. Most of the economically available yield from surfaces water resources has been fully developed and utilised, and opportunities for developing new and economic dams are few. A recent study done by the Department of Water Affairs (DWA) highlighted that the country is more likely to face future water shortages than surplus in the near future [12].

\subsubsection{Urbanisation in South Africa: residential and commercial water use in context}

Key demographic observations indicate that at South Africa's population is growing at 1 percent a year, and by 2030 , it is projected to be growing by 0.5 percent [13]. This does not mean that the population is not growing, it's only growing at a slower pace. Today, about 60 percent of the population live in urban areas (which include almost half of the country's poor people). Urban areas require 30 percent of available water, compared to 70 percent rural (this is mainly due to land uses such as mining and agriculture) - indicating impact that these "rural" land uses on available water [10]. The population living in urban areas is expected to increase from $60 \%$ to $70 \%$ within the next 15 years [13].

While local government is responsible for providing water to residents and businesses, they have little or no control over the largest water users: agriculture, mining and power generation (these users receive water directly from water boards). Local governments must therefore focus policies where it can have some effect: on residential, commercial, and government demand [14].

\subsection{An inefficient urban form}

Population and economic growth inevitably create more demand for water. How and where that growth takes place affects how much additional water is needed and how much it will cost to deliver. The most common type of new conventional 
growth - large lots, low density, and dispersed development - all increase the cost of delivering water.

- Homes on large lots and commercial facilities often consume large quantities of water for lawns and landscaping. Lawn care, car washing, swimming pools, and other outdoor uses can account for 50 to 70 percent of household water use.

- Low-density, dispersed development requires longer pipes, which lose more water through leakage and raise transmission costs (6-25\%) [16].

- Infrastructure investments that support water system expansion instead of upgrading and maintaining existing networks can lead to increasingly inefficient systems, greater waste, and higher capital and operating costs [7].

- Location of development beyond urban development boundary can reduce return on investment in infrastructure - adding new developments to the existing network spreads the system's capital costs over a larger customer base, lowering the cost of water service per customer [14].

- Inappropriate land use near water sources could potentially lower downstream water quality (for example locating landfills near aquifers) [7].

- Reconstruction and development programmes (though well intended) places a burden on existing water sources as this is often accompanied by policies such as free basis service delivery or an unaffordable high level of service.

- Service costs associated with water infrastructure are strongly influenced by a development's location and density (urban form). Therefore, any new system should be located within existing, growing communities (in the form of infill development) as opposed to the creation of new infrastructure on the periphery of the city [14].

The Department of Water Affairs (DWA) has embarked on a nationwide waterreconciliation study, they found that surface water availability and its remaining development potential will be insufficient to support the growing economy and associated needs in full. Water development potential only exist in a limited few water management areas, whilst serious challenges remain in the majority of water management areas [12].

\subsection{Current institutional and legislative context.}

The management of water sources (dams) currently happens at a national level through the DWA. The distribution of water from its source to its clients is the constitutional responsibility of local government (metros, local or district municipalities who act as the water services authorities and often also water service provides for all communities in their areas of jurisdiction. Plans at this level includes water services development plans (WSDP) which must be updated on an ongoing bases. The WSDP integrates technical, social, institutional, financial and environmental planning and feeds into the integrated development plan process [12]. 
Spatial planning (to date) happens at a municipal or district municipality level through the Spatial Development Framework. In theory the SDF must be aligned to the integrated development plan (same as the WSDP). Land uses are managed on a municipal level through a land use scheme (also called zoning code, zoning scheme or town planning scheme) [17].

Reviewing the above it would seem as if all basis are covered. In practice, very if (if any) of the above plans are in fact aligned with each other. The result thereof is that planning for water supply and planning for water demand (as expressed through population and land use growth) is disconnected. An example of this can be seen in the Greater Tubatse Municipality in South Africa, where large planned developments (to accommodate an urbanising population) never happens due to no available bulk water $[17,18]$.

\section{Changing legislation - spatial planning and Land Use Management Act}

Recent court cases involving land use management and urban planning in South Africa led to the development of the new and recently enacted Spatial Planning and Land Use Management Act (SPLUMA). One of the key principles of the Act is the active pursuit of sustainability through the promotion of integrated planning and the involvement of various sector departments in formulating planning documents at various levels of government [19].

- A National Spatial Development Framework (NSDF) must take into account policies, plans and programmes of public and private bodies that impact on spatial planning, land development and land use management (for e.g. the national water resource strategy).

- Provincial Spatial Development Framework (PSDF) which must be consistent with the NSDF. The PSDF must coordinate, integrate and align provincial plans and development strategies with policies of national government, provincial departments and municipalities (this could also imply, policies and plans develop by water service authorities whose boundaries overlaps with local municipal boundaries).

- The Municipal Spatial Development Framework (MSDF) must give effect to the development principles and applicable norms and standards set out in Chapter 2 (this include the principle of sustainable development as mentioned earlier in this document). The MSDF must identify, quantify and provide location requirements of engineering infrastructure and services provision for existing and future development needs for the next five years (water provision for sustainable development). The MSDF must provide the spatial expression of the coordination, alignment and integration of sectoral policies of all municipal departments (most importantly water management).

- Municipalities must also adopt a land use scheme must give effect to and be consistent with the municipal spatial development framework and determine the use and development of land within the municipal area to which it relates in order to promote. 
It is critical that sector departments from different spheres of government as well as utilities and agencies communicate with one another.

\section{Planning for the future: water sensitive planning - exploring the options}

Many countries have been exploring ways in which cities or built-up areas can take part in protecting water resources. The USA formulated the concept of LowImpact Development (LID), the UK's approach was Sustainable Urban Drainage System (SUDS), and New Zealand formulated their approach as Low Impact Urban Design and Development (LIUDD) [20]. Aiming to integrate all of the above mentioned approaches Australia developed the concept of Water Sensitive Urban Design (WSUD). WSUD refers to the interdisciplinary cooperation of water management, urban design and landscape planning which considers all parts of the urban water cycle, combines water management functions and urban design approaches and facilitates synergies between ecological, economic, social and cultural sustainability [21].

South African needs to identify and protect urban water resources thought innovative planning tools as described above. Spatial planning and land use management must value water as a natural resource playing a critical role in the overall sustainability of the city. South Africa has been given a golden opportunity to adopt a water sensitive planning approach, which includes rethinking the role of strategic spatial planning and land use management and its obligations towards water in the built environment.

Water Sensitive Planning ensures that development interacts with the urban hydrological cycle in ways that: provide the water security essential for economic prosperity through efficient use of the diversity of water resources available; enhance and protect the health of watercourses and wetlands; mitigate flood risk and damage; and create public spaces that harvest, clean and recycle water [22]. It bridges gaps between various sectors and provides a platform for transdisciplinary planning, which is a challenge for sustainable water resources management in cities. Water sensitive planning strategies contributes to biodiversity, carbon sequestration and reduction of urban heat island.

Given the new planning environment as stipulated by SPLUMA, this section will specifically focus on the proposed content of SDF's and a land use scheme and how this can contribute the sustainable planning for the management of water.

\subsection{Integrating water sustainability through innovative spatial planning management tools}

A Spatial Development Framework (SDF) is the principal strategic planning instrument which guides and informs all planning and development, and all decisions with regard to planning, management and development in the municipality. A SDF is a document accompanied by a set of plans that illustrates the future spatial form of the municipality. It uses tools such as nodes and corridors and concepts such as densification, containment, protection and growth areas to 
indicate how land uses in the municipality must be managed to arrive at this future spatial form. In the section below, the legal requirements for a municipal SDF (highlighted in bold) will be discussed with specific reference to water sensitive planning. SPLUMA, in section 21 specifies the content of a municipal spatial development framework as consisting of the following [19].

\subsubsection{Spatial Development Framework and water sensitive planning} Section 21(a) Give effect to the development principles and applicable norms and standards set out in Chapter 2: One of these principles include sustainability. As indicated earlier in the document, water as scare natural resource, is one of the major reasons why cites are currently not sustainable, planning therefore should address this at a policy level.

Section 21(b) Include a written and spatial representation of a five-year spatial development plan for the spatial form of the municipality: The spatial development pattern consist of land uses. Land uses consume water. Therefore the decisions regarding the spatial patterns should also consider the availability of and the impact on water resources. Pro-active planning and water management can contribute to sustainable allocation of water and optimal development of water infrastructure. By aligning development priorities with the availability of water in the municipal area, municipalities will be able to make provision for new infrastructure of redirect development to better allocated locations.

Section 21(c) Include a longer term spatial development vision statement for the municipal area which indicates a desired spatial growth and development pattern for the next 10 to 20 years: See the point made above. This longer term spatial vision should, however, also incorporate the longer term outlook of water availability as well as changing climate considerations such as global warming and its impact on water sources.

Section 21(d) Identify current and future significant structuring and restructuring elements of the spatial form of the municipality, including development corridors, activity spines and economic nodes where public and private investment will be prioritised and facilitated: Corridors, activity spines and economic nodes can either mean future development or redevelopment. Water sensitive planning include the development of blue and green corridors which integrates the different land uses and stakeholders through the development of surface water mitigation measures. Blue-green corridors imply retaining stormwater from small, frequent rainfall events at the source of public-, residential- and commercial buildings, through the use of source and site control measures such as rainwater harvesting, green roofs or rain gardens.

Section 21(e)(f) Include population growth estimates as well as estimates of economic activity and employment trends and locations for the next five years: This is most important in order to quantify future water demand. If the population growth and water allocations do not match, serious considerations must be given to innovative rainwater harvesting technologies. Municipalities must identify the development pressures presented by local economies. The vision must be supported and aligned with the water service delivery plan of the municipality. 
Section 21(h) Identify, quantify and provide location requirements of engineering infrastructure and services provision for existing and future development needs for the next five years; include an implementation plan comprising of sectoral requirements, including budgets and resources for implementation: Knowing the cost of water utilities and the cost of water infrastructure can have a significant impact on the size, location and density of development. Often land use planning or proposals are done WITHOUT taking into account the availability of infrastructure or the cost of establishing adequate bulk infrastructure and reticulation. This should in fact be an iterative process. The planning scenario should be measured against the infrastructure cost, if the answer exceeds available infrastructure or the cost of establish capacity, the planning scenarios should be adapted to be in line with capacity constraints.

Section 21(j) Include a strategic assessment of the environmental pressures and opportunities within the municipal area: Preserve open space, farmland, natural beauty, and critical environmental areas. Address water resource issues and conservation of biodiversity at the catchment and sub-catchment level.

Section 21(m) Provide the spatial expression of the coordination, alignment and integration of sectoral policies of all municipal departments: This very important principle should enforce cooperation between the planning department and the department responsible for water. Often this is not the case - the spatial development framework (compiled by the planners) and the water services delivery plan contradict each other.

\subsection{Alignment of Spatial Development Framework and a Land Use Scheme}

While a SDF provide an indication of acceptable land uses or intensity of land uses in certain geographical areas, land use rights are managed though a land use scheme. This scheme can be amended to reflect new or additional land uses or land use rights. Because the aim of the SDF is to provide an overview of the future spatial form of the municipality, it is the primary tool used to decide if a change in land use rights (through the amendment of the land use scheme) should be allowed. In the past, this link between planning tools has been tenuous at best, but SPLUMA specifically calls for a stronger linkage by insisting that a SDF:

- determine the purpose, desired impact and structure of the land use management scheme to apply in that municipal area;

- $\quad$ propose (as part of the implementation plan) a list of amendments to the land use scheme that is necessary to achieve the aims of the SDF; and

- propose geographical areas where the normal processes and procedures of changing land use/rights may be shortened as a way to ensure that the spatial objectives of the SDF will be met.

\subsubsection{Land use schemes and water sensitive planning}

Section 24(2)(a) Include appropriate categories of land use zoning and regulations for the entire municipal area: Zoning for groundwater protection directs development away from groundwater-sensitive or aquifer recharge areas and prohibits potentially polluting uses. A land use scheme must be aligned with 
environmental policies and plans, therefore, zoning codes and scheme clauses can and must address site-specific ecological conditions. "Overlay zones" can protect stream corridors, lakeshores, and watersheds thereby maintaining and improving the water quality - even as the community becomes more developed. An overlay zone can protect water quality by setting additional standards for development and by incorporating site-specific review procedures. These site specifics include building lines, boundaries, densities [23].

Zoning can regulate development by directing development to appropriate locations, requiring development to be setback from riparian areas, limiting the total impermeable site coverage, establishing appropriate lot sizes, limiting or enhancing density, requiring appropriate drainage, and prohibiting potentially polluting uses in areas where aquifers must be protected.

Section 24(2)(b) Take cognisance of any environmental management instrument adopted by the relevant environmental management authority, and must comply with environmental legislation: Protect ecological and hydrological integrity - Use natural channel design and landscaping to ensure that the drainage network mimics the natural ecosystem. Control sediment-laden runoff from disturbed areas, in particular during construction of developments. The land use scheme must include groundwater recharge and conservation regulations where environmental management authorities aim to limit impermeable areas, drainage, and keeping permitted uses to those that are nonpolluting

Section 24(2)(c) Include provisions that permit the incremental introduction of land use management and regulation in areas under traditional leadership, rural areas, informal settlements, slums and areas not previously subject to a land use scheme: Recognise the need for site-specific solutions and implement appropriate non-structural and structural solutions. Install rainwater tanks to collect rainwater to supply toilet flushing and outdoor uses. Minimise the use of hard engineered structures.

Section 24(2)(e) Include land use and development incentives to promote the effective implementation of the spatial development framework and other development policies: Provide incentives through the use of rebates for implementation of on-site measures which may reduce the need for drainage infrastructure upgrade. Ensure developments incorporate water efficient appliances. Ensure fit for purpose reuse is incorporated on site or in the catchment. Land Use Scheme and development controls have the ability to incentivise developers on a financial or non-financial manner. Typically, incentives are linked to existing dwellings or retrofit situations where opportunities for implementing of water sensitive planning and site design elements. Non-financial incentives include for example, increasing the allowable floor-space ration, or increasing the impervious area of a residential allotment, provided the development includes sustainability initiatives such as rain water harvesting, living green walls, water reuse and water efficient appliances. 
Section 24(2)(f) Include land use and development provisions specifically to promote the effective implementation of national and provincial policies; and give effect to municipal spatial development frameworks and integrated development plans: Ensure water management planning is precautionary and recognises intergenerational equity, conservation of biodiversity and ecological integrity. Protect waterways by providing a buffer of natural vegetation to urban development. Use of native vegetation in all runoff management measures and all landscaping to maximise habitat values.

By developing effective, adaptive and innovative water sensitive spatial development frameworks and land use schemes, sustainable management of the total water cycle in urban areas can be accomplished.

\section{Conclusion}

The link between the land use and provision of infrastructure is evident in the development principles of spatial planning highlighted in the SPLUMA. In order to plan sustainably, spatial planning and land use management systems must consider all current and future water resources, and costs thereof, to all parties for the provision of infrastructure and social services in land developments. SPLUMA also requires that Municipal Spatial Development Frameworks and land use schemes identify, quantify and provide location requirements of engineering infrastructure and services provision for existing and future development. Land development must optimise the use of existing infrastructure and needs to introduce innovative surface- and groundwater protecting tools to fight against the looming water scarcity reality.

The focus of spatial planning in South Africa has been redirected adopt a national, provincial and local municipal planning system which is integrated with all sectors impacting on development. If implemented according to law spatial planning and land use management can and will provide water security in near future.

\section{References}

[1] Rhimes, S., GoodReads, 2014. Online: https://www.goodreads.com/author/ quotes/3888197.Shonda_Rhimes

[2] Taylor, N., Urban Planning Theory since 1945, 1st ed., London: SAGE, 1998.

[3] UN-HABITAT. Urban Planning for city leaders, 2nd Edition ed., Germany: Swedish International Development Cooperation Agency, 2014.

[4] Brundtland Commission. Report of the World Commision on Enviroment and Development, United Nations, 1987.

[5] Robeco \& RobecoSAM. Measuring Country Intangibles, 2013. Online. www.robecosam.com/images/CS_Ranking_E_Rel.FINAL.pdf

[6] Ruble, B., The Challenges of the 21st Century City. Wilson Center, Washington, DC, 2012. 
[7] The World Bank Institute. Sustainable Urban Land Use Planning - Module 03: How to Integrate Land Use and Infrastructure. The World Bank Institute, 2014.

[8] Verbeek, J., Developing Countries Need to Harness Urbanization to Achieve the MDGs: IMF-World Bank report. The World Bank, Washington, DC, 2013.

[9] Kevin, K., Ann, F. \& Carissa, S. Is There a Role for Evidence-Based Practice in Urban Planning and Policy? Planning Theory \& Practice, vol. 10, no. 4, pp. 459-478, 2009.

[10] Department of Water Affairs, National Water Resource Strategy2, Republic of South Africa, 2012.

[11] McMahon, T \& Peel, M., Global stream flow Part 3: Country and climate zone characteristics. pp. 272-291, 347.

[12] Department of Water Afairs. Strategic Overview of the Water Sector in South Africa 2013. Pretoria, 2013.

[13] National Planning Commission. National Developemt Plan - Vison of 2030. Pretoria, 2011.

[14] Van Lare, P. \& Arigoni, D. Growing Towards More Efficient Water Use: Linking Development, Infrastructure and Drinking Water Policies. United Sates Enviromental Protection Agentcy, Washington DC, 2006.

[15] American Water Works Association. Fact sheets. 2004. Online. www.awwa.org/pressroom

[16] Calgary Region Focus. Let's talk density. 23 Febuary 2013. Online. http:/www.calgaryregionfocus.com/2013/02/20/lets-talk-density/

[17] W. Fourie, Interviewee, Spatial Planning and Land use management in South Africa. [Interview]. 18052014.

[18] Glen Steyn \& Associates. Greater Tubatse Local Economic Development Strategy. Greater Tubatse Local Municipality, Greater Tubatse, 2007.

[19] Rural Development and Land Reform. Spatial Planning and Land Use Management Act No. 16 of 2013. Republic of South Africa, Pretoria, 2013.

[20] Rohr, H.E.,Water Sensitive Planning - An integrated approach towards sustainable urban water system planning in South Africa. North-West University Potchefstroom, Potchemstroom, 2012.

[21] Wagner, I., Water Sensitive Urban Design Task Group. SWITCH, 2010.

[22] CRC. Water Sensitive Cities. Australian Goverment Inisiatives, Melbourne, 2014.

[23] Russell, J., Overlay Zoning to Protect Surface Waters. 2014. Online. http://plannersweb.com/2004/04/overlay-zoning-to-protect-surfacewaters/ 